\title{
Nepal's Political Relationship with India: Under the Lens of Path Dependency Theory
}

Gaurav Raja Dahal

\begin{abstract}
The recent developments in Nepal's politics from the abolition of autocratic monarchy, promulgation of a new constitution to successful completion of local, provincial, and federal level elections can be perceived as Nepal's politics achieving miraculous success in forming democracy. Throughout the history, heavy reliance on the Indian economy has been considered as a major hurdle to Nepal's sovereignty. This paper analyzes the Nepal-India relationship through path-dependent theory and argues that with series of above mentioned democratic success, the contemporary Nepali foreign policy towards India is at a critical juncture where Nepal can incorporate new changes to make its policies independent and uninfluenced by the Indian government. Analyzing the series of political and democratic events and foreign policies implemented to date, this paper aims to understand how the Nepali leadership can utilize these recent series of democratic successes as a turning point to break the traditional approach of forming policies to appease the Indian government and receive political and economic support and implement new policy changes leveraging on the multilateral organizations and developmental partners for its support economically and politically.
\end{abstract}

Keywords: critical juncture, interdependence, multilateralism, Nepali foreign policy, path dependent

\section{Background}

Nepal is a developing and landlocked country located between the two big Asian superpowers, India and China. As a small nation with inadequate structural power, Nepal's foreign policies and development aspects regarding economy, military, social, and politics are contingent and focused on its two superpower neighbors. Throughout history, heavy reliance on the Indian economy for the majority of its trade has been perceived by Nepali people as a serious problem to Nepal's sovereignty. India serves as the major market for export of Nepali commodities. $60 \%$ of Nepali economic activities are directly connected with India, whereas $80 \%$ of imports are done through India, which provides the only access to sea through port of Calcutta (Nayak, 2016).

Over the years, the growing economic dependency on India has augmented and has also bred "anti-Indian sentiments". Nepali people consider Nepal's worsening condition as leeway for India to exert influence and induce Nepal to formulate policies according to its liking. Moreover, the leading political parties of Nepal have also been consistently unable to state or implement domestic and foreign policies that are beneficial and in Nepal's interests, especially those that can abate the vulnerable situation of Nepal. This has also been the major reason for the lack of unity among the political leadership in Nepal as these policies are formed solely based on their interest and gains (Dahal, 2011).

India has been assisting Nepal in most of the political and economic issues throughout the history, but during
2015, India became unable to resolve the situation diplomatically and started playing a "big brother role" towards Nepal, mishandling the situation. Unable to bring new sophistication to the diplomacy, the Indian government imposed an unofficial economic blockade over Nepal. It consequently drove Nepal off to its major regional rival China. After the unofficial Economic blockade, when the anti-Indian sentiments among Nepali people were at the peak, Communist party of Nepal was able to garner people's trust over their counterpart, Nepali Congress, which was closer to the Indian Government. "Oli became a symbol of this anti-India sentiment and his election victory was a result of his standing up to Indian hegemony" (Pant, 2018). Oli's speeches included the agenda of non-inclination and increased relationship with the Chinese government. People, who were dejected having already faced two devastating major earthquakes in 2015, were struggling with shortages of essential commodities because of the blockade imposed by India. The blockade enraged them and filled them with an unprecedent level of hatred towards the Indian side. Oli's aim to have a mutual relationship with its two neighbors and to decrease the economic dependency over Nepal significantly were welcomed by angered citizens of Nepal.

Morin, Jean-Frédéric, and Jonathan Paquin, in their book Foreign policy analysis, state that the statesman's decision in certain period can reflect the necessity of that period but in the future, it may also have negative consequences and not be able to change the track. Similarly, Oli's policies of non-inclination and economic independence for achieving public support can be perceived as his policy of dragging Nepal out of the vulnerable economic situation. 
His policies' main focus was to decrease the economic dependency over India. To achieve this goal, his focus was to enhance the economic relationship with China.

Similarly, the Nepali people who had already suffered a lot from two major earthquakes of April 2015 faced an economic blockade imposed by the Indian government. They were furious with the Indian government and was dissatisfied with the government of Nepal. Oli who advocated for the symmetrical relationship with India advocated for enhancing the economic relationship with China through the development of hydro-projects, railways, and Foreign investment. Oli advocated for the development of railways, hydro-projects, and enhancing of the environment welcoming foreign investment inside the country. This slogan of economic development and prosperity had a significant impact on people angered by the blockade. They started showing their appreciation and support for Oli's agenda. Therefore, this way, Nepali Congress which was the leading political party in Nepal was defeated by the Oli-led leftist party in the national election.

\section{Methodology}

The research techniques for this paper is descriptive, observational, and analytical. Numerous research reports by various NGOs and INGOs, government organizations, civil societies, and independent agencies was surveyed for secondary information.

The study applies IR path dependency theory as proposed by Fioretos, Pierson, Schreyögg, Steinmo, and others. The research focuses on the historical and contemporary relationship of Nepal with India and to generate an academic understanding of Nepal's critical foreign policy. The outcome of the research is based on the answers derived from the analysis through this approach. Subsequently, this approach is used and analyzed for the justification and relevance of the methodological approach to this research. The reasons and compatibility of this theory chosen are also justified.

\section{Literature review}

Nepal has geo-political advantage because it has two economic and technological superpower countries as its neighbor with a huge population, huge markets, and industries (Dahal, 2011). He also states that, historically, Nepal has been able to maintain its close relationship with both its neighbors than they can maintain with each other.

In the past, Nepal was constitutionally a country with a Hindu majority where the ruling class has always been the elites from Hindu society. The Indian states of Uttar Pradesh, West Bengal, and Bihar bordering with Nepal also consist of the people sharing the same religious and cultural ties with Nepali people. Due to this, most of the policies and patterns implemented by the Nepali government were significantly directed towards appeasing the GoI. Similarly, Dahal also states that, in recent times, as Nepal is galloping towards a more secular system providing privileges equally to all its people, achieving democratic successes.

Historically, Nepal has a bitter experience of being defeated and being compelled to sign treaties and agreements where it lost its territories, trading rights, and most of all the national integrity as it was not able to maintain the evenly balanced mutual dependence between its two superpower neighbors, with China in $18^{\text {th }}$ century and with British India in $19^{\text {th }}$ century because of being relatively small power and having lesser resources than these two states (Dahal, 2011). According to Muni, in 1950, when the Sino-Indian war occurred, it was necessary for Nepal to maintain a relationship with China as well. King Mahendra attempted to diversify its relationship and adopted the non-alignment policy by extending the diplomatic relationship with the US, China, Soviet Union, Japan, and others (Muni, 1973). The major reason for Nepal to pursue this strategy for diversifying and backtracking India's special relationship was to balance the interdependence between its neighbors and set itself free to pursue its national interest in the International System. With this strategy, Nepal aimed to decrease its overall dependency and security challenges with India. The development of Nepal, either it be economic prosperity, political development, or national security, significantly depended on how it managed the relationship between its two neighbors and represents itself and contributes to the international arena (Dahal, 2011).

As Pierson and Theda in historical institutionalism in contemporary political science stated "Outcomes at a "critical juncture" trigger feedback mechanism that reinforces the recurrence of a particular pattern into the future" (Pierson \& Theda, 2002, p.6). After the abolition of the monarchy and declaration of Nepal as a secular state by the new government after 2006, Nepali people suffered from the identity crisis increasing more differences regarding their ethnicity, class, religion (Dahal, 2011). These differences have been the major reason for Nepal straining to achieve a single national interest and achieve political stability because regional and religious identities are gradually becoming national identities. These differences of identities have made the country's political system unstable. Political parties provoking these differences for their survival-oriented strategies has resulted in creating extractive political and economic institutions further worsened by the adverse political condition in Nepal.

\section{Conceptual Framework under the Path Dependency Theory}

The policies implemented by any country towards another are often based on the historical experiences and interactions that have been able to set an imprint over the relationship between them. These events can be considered as an important factor for having restrictive or open policies that the country currently has with another. According to this approach, as the decision-makers implement certain policies, it becomes relatively difficult to change the track in the future (Morin, 2018). The policies implemented in a certain period also reflects the political or cultural necessity suitable for that particular period.

In Historical Institutionalism in Contemporary Political Science, Pierson and Theda analyzed the fundamental 
process and its outcomes of events during different phases of times in history. This approach also plays a significant role in understanding the statesman as an individual and as an agent of history (Steinmo, 1992). "To understand an interesting outcome or set of arrangements usually means to analyze processes over a substantial stretch of years, maybe even many decades or centuries" (Pierson \& Theda, 2002, p.5). Through this approach Nepali foreign policy towards India can be traced thoroughly which will further provide the evidence to support the claims this paper will be providing. Similarly, careful analysis of these past trends and patterns is important because they may help us understand the possible outcome from the policies from the past and under various conditions.

\section{Analysis Through Path Dependency Theory}

Nepal has never been colonized by any country throughout its history. However, Nepal faced an autocratic Rana regime and Shah regime that had their own ways of making decisions and policies and imposing on people. Nepali people were sovereign but not independent. The main objective of Rana's and Shah's foreign policy was the survival of their regime which was only possible by the recognition and acceptance by the British empire of theRanas regime. Similarly, the Indian Government's support remained the same even after the reestablishment of democrocacy.

The Nepali foreign policies before the abolition of the monarchy were always formed either with the influence of the royalties or by the Indian Government (Rose \& Dial, 1969). These decisions were never free from the influences of the actors seeking their own self-interest. Throughout Nepali history, the regime repeatedly was involved in construction of the extractive political and economic institutions as an attempt to grab all the power for its own control. Nepali people have always been sensing the lack of independent government with an independent economic and political system that is democratic and responsible towards its citizens. This had caused the rise in antimonarchy sentiments among Nepali People where they stood up and revolted against the autocratic monarchy whereas, the rise in anti-Indian sentiments gave rise to the communist party in recent times.

We can see there were many steps taken to shift the dependency from India throughout history. The 1962 Sino-India war showed that China was also a powerful nation next to the Himalayan borders and it was of Nepal's security interest to have friendly relationship with it as well. As Nepal witnessed the power and aggression of the Chinese government, it became clear to Nepal that it has to maintain its relationship with both of its neighbors. Having a good relationship with only one of them could have a fatal effect on the country. King Mahindra tried to balance the relationship from 'special relationship' to 'balanced relationship' with India by signing trade and aid agreements with China as well. This can also be considered as his attempt to reduce the significant amount of economic dependency over India in search for partnership with China which could have resulted in mutual benefits.

\section{Instrumental Self-Reinforcing Sequence (SRS)}

Historically, whenever the policies implemented by the GoN were formed against the slightest interest of India or displeased the Indian government in any way, the Indian government imposed blockade from time to time in an attempt to influence Nepal's vulnerability and bring Nepal on it's terms. For instance, In an attempt to pressurize Nepal, Indian Government imposed the first trade blockade in March 1989 on Nepal. "Among the irritants that may have motivated the Indian government action was a mid1988 Nepal decision on Chinese arms purchases and the levying of a $55 \%$ tariff on Indian goods entering Nepal" (Koirala, 1990, p.136). India closed 19 out of its 21 borders that were connected to Nepal. Therefore, understanding the influence of GoI, Nepali leadership are always wary about the policies they are forming. Because there is a sense of fear in the political parties that change in these policies may provoke the Indian government and their regime will be in danger. The steps by Nepali leadership to achieve a balanced relationship sharing mutual benefits with both its neighbors were unsuccessful because of the series of Indian government-imposed blockade during 1970, 1969, 1989, and 2015 (Pant, 2018).

According to the SRS approach, during the times of war and crisis, a country will try to reconstruct its system with new policies and plans that it might feel necessary to overcome the difficult situation (Gourevitch, 1986). SRS based critical juncture theory states that these types of suboptimal policies are implemented by the country in its tough times, considering the necessity of that certain period only. These policies are formed and implemented without anticipating its drawbacks and negative effects in the future (Morin \& Paquin, 2018). These decisions from the past can limit the future choices making abilities of a decision-maker. When the newly implemented policies solve the problems, then they are credited for the successes and succeeding the instrumental SRS theory, the beneficiary credited for the success of implementing the policies will do their utmost for the consistent implementation of the policies and struggle to achieve more power (Schreyögg \& Sydow, 2009).

\section{Influence Through Treaties and Agreements}

Every treaty's major function is to protect its stakeholders' future interests. However, if it fails to do so then the obvious way out is to amend or quit these treaties (Manhas \& Sharma, 2014). India-Nepal treaty of Peace and Friendship of 1950, which is also considered as one of the major treaties between Nepal and India, has significant influence over the relationship between these two countries. This treaty has been a milestone in establishing the friendly relationship between these two governments and agreement of mutual dependence in trade and commerce and security. But in spite of the results, this treaty has always been the subject of debate as it is considered to have generated an asymmetrical relationship between Nepal and India, benefitting India more than Nepal.

This treaty was signed when Nepal was still under the autocratic Rana regime. Before 1947, Rana had a 
good relationship with the British government which had colonized India. This relationship made Ranas forgo any threats and insecurity to their regimes from external actors and were only focused on maintaining the internal political system. After the British withdrew from India, Ranas realized that it was important to maintain the relationship with newly independent India. Therefore, in an attempt to maintain the relationship with this new democratic country, Rana agreed to sign Treaty of Peace and Friendship in 1950. This treaty was based on the agreement that the Indian government will recognize Nepal's sovereignty and assist the country for development processes whereas the Nepal government will cooperate with the Indian government in security issues.

Similarly, as explained above, in the context of the Nepal-India relationship the Treaty of Peace and Friendship of 1950 has been the major issue for the strained relationship between India and Nepal. As the world saw the Chinese aggression followed by Chinese claim on Tibet, the major driver for this treaty by the Indian government was this fear of Chinese claim on Tibet and for Nepal from the fear of the Indian government supporting the democratic movement growing in Nepal. According to the SRS approach, this treaty can be seen as the sub-optimal policy choice that Nepal undertook. With this treaty, GoI envisaged Nepali territory under its security framework to deal with its rival China. Therefore, throughout history India can be seen as using this treaty as an instrument to stop Nepal from enhancing its relationship with China, compromising the Indian government's security concerns (Subedi, 1994).

As examined earlier, Rajiv Gandhi led the Indian Government to impose an economic blockade of 1989, showing the issue of expiration of this Trade and Transit of 1950, was also directed towards to the enhancing relationship with China (Koirala, 1990). To cope up with this, India imposed a blockade, Nepali government imported fuel from Bangladesh and made further arrangements to import fuel from China during the crisis. The Nepali government also appealed for help with the International Community where it got concessions from the World Bank and other donor agencies in form of loans (Bhattrai, 2015). The major reason for this issue was that the GoN blamed the treaty to be outdated whereas the Indian government blamed Nepal for violating the treaty.

Similarly, If the policies implemented and institutions do not have any positive feedbacks than these policies and institutions can no longer exist as they will be vulnerable to change (Keohane \& Nye. 2001). They also state that any actor will attempt to manipulate or changes the policies if they will suffer loss and is disadvantageous for them. They will try to implement the best policy from their policy alternatives that will provide advantages and gains.

Nepal is also a country that has huge potential for hydro-electricity generation. Despite this potential, Nepal has not been able to utilize its resources because as a poor developing country, it lacks capital as well as technical knowledge. It requires external support to be able to produce and sell hydroelectricity and ensure optimum utilization of this resource. India is a huge country with a huge population; therefore, to cope with the scarcity of water for drinking and irrigation purposes, it is continuously attempting to use water resources from Nepal. Nepal and India have also engaged themselves in many water agreements and treaties. Despite these treaties and agremments, Nepali hydropower projects also faces the problem of Indian monopoly. The Koshi Barrage Project of 1954 and Gandaki barrage of 1959 were agreed to be built by both the governments backed by GoI's Finance Ministry, but most of the Nepali people perceived that the GoI was exploiting Nepal citing that this treaty is biased towards India and serves its purpose rather than both the parties involved; therefore, this agreement was against the national interest (Swain, 2018).

\section{Analyis Under the Concept of Critical Juncture}

When analyzing the history, we can understand that Nepali political leaders cannot pursue their independent policies without the influence of GoI. For instance, their first respective foreign visits to India always have been perceived as they are used to follow the trodden path from their predecessors lacking the capabilities to pursue anything except searching the influence of the Indian government in their policies. Therefore, these policies show more of India's interest in Nepal rather than addressing the interest of Nepal. In some cases, mentioned above, whenever the Prime minister of Nepal tried to change this path by making China as their first foreign visit, it can be perceived as they trying to enhance their relationship with China.

\section{Political Instability}

After the abolition of the monarchy, there have been several changes in the leadership of the country. Any political leader has not been able to stay in the post of prime minister for very long. Therefore, the major aim of these political leaders is to fulfill their own needs in their short period of time as prime minister before they have to leave the post. ${ }^{1}$ This can be in terms of posting their relatives in the government post or receiving commissions bypassing the agreements and tenders on different governmental projects and government-owned companies which are not feasible. In the case of Nepal, the system works from a top-down direction, therefore the corruption and abuse of the authority start from the top of the system. For instance, in 2012, when Maoist leader Baburam Bhattrai was Prime Minister, he appointed his sister Timila as the head of Kathmandu Valley Drinking Water Pvt. Ltd. (KUKL) which was a state-owned company which was considered 1. According to the report of 2018 provided by Transparency International, Nepal ranks $124^{\text {th }}$ among the 180 countries in the corruption. Retrieved from https://www.transparency. org/cpi2018. The survey conducted by the CIAA of Nepal shows that the local governments, municipalities and rural municipalities are the most corrupt institutions in Nepal. For more information, see Achin Vanaik. 2008. The new Himalayan republic. Transnational Institute. Retrieved from https:// www.tni.org/my/node/13781 and Ram Dayal Rakesh. 2019. Corruption at high level: Political will lacking to control it. The Himalayan Times. Kathmandu. Retrieved from https:// thehimalayantimes.com/opinion/corruption-at-high-levelpolitical-will-lacking-to-control-it/ 
an abuse of his authority. In comparison to Acemoglu and Robinson's theory, Nepali political institutions are also based on 'extractive institution', where the statesman is always trying to exploit the people and fulfill his own desire.

Similarly, Acemoglu and Robinson also state that another reason for the fall of a state is because of the neighbor's policy as well. It holds true especially in Nepal's case because Nepal, sandwiched between two superpower countries, is vulnerable because it cannot defend itself economically and militarily. It cannot even survive without the support and aid from these neighbors. It has been proven correct from the series of economic blockades that have been imposed by India. These blockages can have a devastating effect on the economy of Nepal as well as the daily lives of the people.

For instance, during the monarchic period, Kings were the most powerful person in the country. They were considered to be above the law and was able to form and implement policies according to their will. They also had the support of the people who trusted them to be an incarnation of the Hindu god "Vishnu". The monarch had well-informed advisor that we're able to provide rational decisions that were essential for achieving national interest. The foreign policies made during Shah Kings were based on the understanding of Nepal's geographical constraints and ways to overcome them, especially regarding the relationship among its two powerful neighbors.

Also, during Rana's autocratic regime Nepal was in a state of isolation. The Ranas were concerned about the survival of their regime. Therefore, they only tried to maintain their best relationship with the British Empire. This way they achieved recognition for their regime which was mandatory for their survival. They were just liable to the British empire for the policies they made. The main aim of their policies was to appease the British and have a strong relationship for maintaining the regime. They neglected to maintain a relationship with other nations or the international system. They cherished the state of isolation maintaining the external contact with only the British empire. They only made connections with the UK, USA, India, China, and France.

But, in recent times after the abolition of monarchy, there has been a continuous change in the political leadership in Nepal. These continuous changes have made them unable to pursue the national interest and are always striving for their personal interest during their short term. Even though Nepal has achieved miraculous development in the democratization process, no major accomplishment has been observed in its economic development. Even though economic prosperity and development, following the principles of Panchsheel Agreement, non-alignment, UN Charter and international Law to balance the relationship with India and China was the major goal to promote national interest (Claude, 2004). Like every other statesman, Khadga Prasad Sharma Oli (K. P. Sharma Oli) also became highly involved in maintaining the relationship with the neighboring countries (Wagle, 2018).

\section{Policies to Address Non-State Actors and Developments Partners}

In this stage of globalization, the country's policies have major effects not only on the country itself but on other countries and other non-state actors. Before, Nepali leadership was forming policies just based on the Indian government's influence to fulfill their own self-interests than to achieve economic prosperity. In recent times, there is the presence of many development partners within Nepal Now, Nepal has to address their interest as well before formulating and implementing any major policies. Moreover, in the time of crises due to blockade and insurgency, there was an international community that helped Nepal.

They have significant importance in sustaining the sovereignty of Nepal and providing the Nepali people with their independence. The international community was the one who was not willing to accept that the Maoists take over the Government of Nepal, which initially led the insurgents to come for peace talks. They also did not support the takeover of power by the monarchs, pressuring them to return the freedom to the people. When the revolution took place, the monarch had to listen to the voice of the people because they had immense pressure from these international communities. Therefore, Nepal recognizes the importance of these international actors and their ability to provide Nepal with an independent support system even though it is a landlocked country.

GoN started its venture with the global community by attending the Afro-Asian Conference in 1955 which was held in Indonesia. Following that, Nepal achieved the membership of the United Nations (UN) in 1955 which was its initial step to interact with the international regime. Before this, Nepal was in a state of isolation where it only maintained the relationship with the British colonizing India. With the attainment of this membership, Nepal realized it seriously lacks the capabilities and experiences to play a significant role in international politics. Therefore, understanding this lack of ability, Nepal gradually started enhancing its connection with the international community. Similarly, Nepal became a member of the International Monetary Fund (IMF) and the World Bank (WB) on September 6, 1961. Nepal got the membership of the Asian Development bank in $1966 .{ }^{2}$ Nepal has also been strongly advocating for the smooth operation of the regional organization like the South Asian Association for Regional Cooperation (SAARC). Nepal entered the Bay of Bengal Initiative for Multi-Sectoral Technical and Economic Cooperation (BIMSTEC) in February 2004. It also held the fourth BIMSTEC summit in Kathmandu in 2018. These steps of Nepal can be perceived as its increasing interest in involvement in the international arena. These multilateral engagements steps can also be regarded as a liberal approach by GoN towards achieving developments because in time of necessity either it is from the economic blockade imposed by the Indian government or the Maoist insurgency period, Nepal called for the international community for help and support.

2. Retrieved from https://www.adb.org/about/members 
Nepal understood that being a landlocked country it will be harzard if the country just maintains a relationship with its neighbors, with the crisis of economic blockade Nepal understood the importance of the International community and multilateral agencies.

According to Beasley, there is continuous development on the interdependence among the states- "from the internet to satellite communications technology to global financial networks" (Beasley, 2012). This increase in interdependence has enhanced connections between many countries i.e. politically, for technologies, militarily, and especially regarding the economy improving the process of globalization. With this enhancement of globalization and economic liberations, democratization around the world where people are demanding for their own representation with their respective government has also gained pace. Externally non-state actors are showing significant interest in the nation's human rights records and internal affairs. Therefore, because of these dynamic environments, both internal and external, states have to form and implement policies that can cope up with these transformations, reflecting the nation's interest without excluding anybody. Therefore, we can understand that with the K. P. Oli's government, Nepal is perceived to have a stable political situation. As Oil's policies were also focused on developing Nepal's economy, his mere attempt to maintain and enhance Nepal's relationship with India and China is not enough. Therefore, he also has appealed to the global community and all major developing partners for support and cooperation.

\section{Policies Based on Ideologies}

In current Nepali politics, we can observe polarization between Nepal's Communist and democratic Parties. This polarization has dragged Nepal to face a unique socio-political environment. Nepali Congress, which is a democratic party and pan-leftist alliances which consists of the Communist Party of Nepal (Unified Marxist-Leninist) and the Nepal Communist Party (United). Even though the Maoist rebels transformed themselves and achieved a huge victory in the 2008 elections. This unification came as a necessity for the communist parties of Nepal as they faced tough times with unorganized party structure and abandoning members by 2013 (Shrestha, 2017).

As already shown, Maoists carried the same ideologies that matched with the Chinese Government. Due to these ideological similarities, Maoists leaders were very keen to enhance their relationship with China. We can understand that, even though the rebelling Maoist party in Nepal have been able to transform themselves into a competing political party following the democratic framework, there will be the ideological difference between the Indian Government who will be closer towards the Nepali Congress (NC) which follows democratic ideologies whereas, the Nepal Communist Party (NCP) who adheres communist ideologies, will be closer towards China who shares the same ideologies.

Indian government has been close to the NC because of their similar democratic ideologies. In recent times, with the communist government coming to power, the prime minister has been seen trying to change the pattern of
India's Influence by making their first foreign visit to China. This step from the prime ministers of Nepal has been done to put the statement to the Indian government that says it is trying to enhance the relationship with China as well. Even after both the Prime Ministers Oli and Dahal made their statement by making the first foreign trip to China, it can be seen that these policies were disadvantageous to them. They had to again change this policy in order to maintain a good relationship with India. Taking Fioretos' statement into consideration, maintaining a good relationship with India can be seen as advantageous for the Nepali leadership because they were not able to achieve positive feedback.

Morgenthau has also stated that a political leader, to achieve people's support, may include philosophical and political sympathies backing up their policies. The policies that are implemented by the leader of any state can be identified as either "official duty" based on achieving the national interest or as "personal wish" based on achieving his own's political principles (Morgenthau, 1973). These sub-optimal policies were made in desperation and lacked any calculation of the future consequences and feedbacks. These policies did not consider the geographical constraints and other political problems that could be caused by disapproval by the Indian government. Finally, when the consequences were realized then Oli has to take prudent steps to mend the damaged relationship with its southern neighbor. Oli's government did not calculate the cost of changing the path i.e. to shift the economic dependence from India towards China.

\section{Conclusion}

The theory of path dependence plays a significant role in understanding Nepal's relationship with India because, with this approach, this paper analyzes the processes of regime change, insurgency period, democratization process and understand a different phenomenon that took place in different periods of time in the history of Nepal. With the help of this approach, this paper has also been able to demonstrate that Nepali Foreign Policy, throughout history, pursued a policy of dependency on India.

At the moment, with the series of democratic successes from the abolition of autocratic monarchy to the promulgation of the constitution, Nepal is in a critical juncture. It has been able to achieve a series of democratic successes, from the abolition of the autocratic monarchy, to peace agreements with Maoist rebels and promulgation of a new constitution. These events coincided with the growing presence of international agencies - development partners, multilateral institutions, bilateral institutions, INGOs - in Nepal. These agencies, in many ways, fostered conducive environments through dialogues and other supports for the changes to take place. As such, with this increasing presence of international and regional institutions, Nepal can utilize this as a turning point to shift its approach of foreign policies from the traditional approach where Nepal can rely for aid and support with these developing partners instead of relying only on India. Nepal can leverage their role further for its developmental purpose as these nonstate actors have increasingly been able to assist countries like Nepal for providing required support for the proper 
shaping of social and political developments (Ju \& Tang, 2011). With this enhancement of involvement with these international and regional institutions, Nepal can also play a significant role in global politics.

\section{Acknowledgments:}

I would like to thank the anonymous reviewers for their careful reading of the manuscript and their insightful comments and suggestions.

\section{Funding:}

Not funded. It was self-sponsored research.

\section{Ethical approval for the research:}

Not Applicable.

\section{Conflict of Interest:}

No conflict of interest.

\section{Ethical Conduct of Research:}

I declare that this research has been conducted with accordance with extant ethical considerations for social research.

\section{References}

Beasley, R. K., Kaarbo, J., Lantis, J. S., \& Snarr, M. T. (2013). Foreign Policy in Comparative Perspective: Domestic and International Influences on State Behavior. SAGE Publications, Inc. https://doi. org/10.4135/9781544308470

Bhandari, S. (2012). The king versus the people: The abolition of monarchy and constitution-making in Nepal. Available at SSRN 2367755.

Bharadwaj, N. (n.d.). Why anti-Indian sentiment grows in Nepal? The Rising Nepal. Retrieved from http:// therisingnepal.org.np/news/8561

Bhattrai, T. N. (2015). Remembering the 1989 blockade. Nepali Times. etrieved from http://archive.nepalitimes. com/article/from-nepali-press/Remembering-the1989-blockade, 2651

Claude, A. (2004). Born in sin: The panchsheel agreement: The sacrifice of Tibet. Mittal Publications.

Dabhade, M., \& Pant, H. V. (2004). Coping with challenges to sovereignty: Sino-Indian rivalry and Nepal's foreign policy. Contemporary South Asia, $13(2)$.

Dahal, D. R. (2011). The art of survival: Policy choices for Nepal. Dhaulagiri Journal of Sociology and Anthropology, 5.

Dahal, G. (2018). Foreign Relation of Nepal with China and India. Journal of Political Science, 18, 46-61. https://doi.org/10.3126/jps.v18i0.20439

Das, B. (2019). Rise of anti-Indian feelings in Nepal: A major security concern for India. International Journal of Research in Social Sciences, 9(2), 730-742.

Fioretos, O. (2011). Historical institutionalism in international relations. International Organization, 65(2).

Gourevitch, P. (1986). Politics in hard times:
Comparative responses to international economic crises. Cornell University Press.

Ju, C. B., \& Tang, S. Y. (2011). ’Path dependence, critical junctures, and political contestation: The developmental trajectories of environmental NGOs in South Korea." Nonprofit and Voluntary Sector Quarterly, 40(6).

Koirala, N. (1990). Nepal in 1989: A very difficult year. Asian Survey, 30(2), 136-43.

Keohane, R. O., \& Joseph S. Jr. (2001). Power and interdependence (3rd ed). Longman.

Manhas, N., \& Sharma, M. (2014). The 1950 treaty of peace \& friendship: An issue of contention between India and Nepal. International Journal of Scientific and Research Publications, 4 (11), 1-5

Morgenthau, H. J, Kenneth W. T., \& Clinton, W. D. (2006). Politics among nations: The struggle for power and peace (7th ed.). McGraw-Hill Higher Education.

Morin, J. F., \& Jonathan P. (2018). Foreign policy analysis: A toolbox. Palgrave Macmillan.

Muni, S. D. (1973). Nepalese foreign policy. National Publishing House.

Nayak, N. R. (2016). Landlocked and transit developing countries: Nepal's transit route negotiations with India. Strategic Analysis, 40(2), 101-121.

OHCHR. (2012). Nepal conflict report. Executive summary. United Nations Office of the High Commissioner for Human Rights, Geneva.

Ojha, H. (2015). The India-Nepal crisis. The Diplomat. Retrieved from https://thediplomat.com/2015/11/theindia-nepal-crisis/

Pant, B. (2018). Socio-economic impact of undeclared blockade of India on Nepal. Research Nepal Journal of Development Studies, 1(1).

Pant, H. V. (2018). Why India needs to safeguard its ties with Nepal. Observer Research foundation. Retrieved from https://www.orfonline.org/research/41945-whyindia-needs-to-safeguard-its-ties-with-nepal/

Pierson, P., \& Theda S. (2002). Historical institutionalism in contemporary political science. Political Science: The State of the Discipline, 3.

Rakesh, R. D. (2019). Corruption at high level: Political will lacking to control it. The Himalayan Times. Kathmandu. https:/thehimalayantimes.com/opinion/ corruption-at-high-level-political-will-lacking-tocontrol-it/

Rose, L. E., \& Dialm R. (1969). Can a ministate find true happiness in a world dominated by protagonist powers? The Nepal cases. The Annals of the American Academy of Political and Social Sciencem 386(1), 89101.

Schreyögg, G., \& Jörg S. (2009). The hidden dynamics of path dependence: Institutions and organizations. Springer, 16.

Shrestha, S. (2017). Is Nepal headed towards the communist state? Al Jazeera News. Retrieved from: https://www.aljazeera.com/blogs/asia/2017/10/nepalheaded-communist-state-171014095129113.html

Steinmo, S., Kathleen, T. \& Frank, L. (1992). Structuring politics: Historical institutionalism in comparative 
analysis. Cambridge University Press.

Subedi, S. P. (1994). India-Nepal security relations and the 1950 treaty: Time for new perspectives. Asian Survey, 34(3).

Swain, A. (2018). Is it water not China that has ruined Nepal's relations with India? Retrieved from https:// www.outlookindia.com/website/story/it-is-waternot-china-that-has-ruined-nepals-relations-withindia/310684

Sydow, J., Schreyögg, G., \& Koch, J. (2009). Organizational Path Dependence: Opening the Black Box. Academy of Management Review, 34(4), 689-709. https://doi. org/10.5465/amr.34.4.zok689

Vanaik, A. (2008). The new himalayan republic. Transnational institute. Retrieved from https://www. tni.org/my/node/13781

Wagle, G. S. (2018). Oli's foreign policy. The Kathmandu Post. Retrieved from: http://kathmandupost.ekantipur. com/news/2018-06-15/olis-foreign-policy.html

Gaurav Raja Dahal, https://orcid.org/0000-0003-2368$5690 \mathrm{He}$ has graduated in International Peace Studies at International University of Japan in 2019. His areas of interest include politics and economy.

Email: dahal@iuj.ac.jp 